\title{
The Determinants of Taiwanese's Employment and Entrepreneurial Intention in Mainland China
}

\author{
Jung-Jen HUANG ${ }^{1}$ \\ Jan-Yan $L I N^{2}$
}

\begin{abstract}
Strengthening cross-strait exchanges and cooperation, and expanding the breadth and depth of Taiwanese employment and entrepreneurship in mainland is one of the main themes of cross-straits economic and cultural exchanges. This paper applied questionnaire survey to analyze the intention of Taiwanese for employment and entrepreneurship in mainland China and its influencing factors. The results show that, in general, Taiwanese are willing to work and start up in the mainland China. In addition, the greater the attractiveness of the mainland, the stronger the core competence, and the higher cognition of mainland China, the greater the intention of Taiwanese for employment and entrepreneurship in mainland China. Finally, based on the analysis, this paper puts forward some suggestions for Taiwanese to go to the mainland for employment and entrepreneurship.
\end{abstract}

KEYWORDS: employment and entrepreneurial intention, determinants for employment and entrepreneurship, Taiwanese, mainland China

JEL CLASSIFICATION: M130, M500, L260

\section{INTRODUCTION}

Because of the global economic downturn after the international economic crisis, the world economy has entered a period of deep structural adjustment. The economic development in Taiwan is also seriously influenced by the international economic crisis, which caused the phenomenon of double decline in interest and investment rate. As a result of the economic downturn, the employment situation of Taiwan is not optimistic (Shan, 2016). According to the statistics, the overall unemployment rate of Taiwan was 3.73\% inApril 2019. More specifically, the unemployment rate of age group 20-24 and age group 25-29 were $11.70 \%$ and $6.46 \%$, respectively, and both of them were higher than the average unemployment rate. It is obvious that youth in Taiwan are suffering from a high unemployment rate. In addition, among the reasons of unemployment, lack satisfaction with the former job and the salary were ranked in the first two places. In order to alleviate the employment problem in Taiwan, the government has promulgated a series of supporting measures to reduce the unemployment rate, including

\footnotetext{
${ }^{1}$ Chung Yuan Christian University (Department of Business Administration), Taiwan, zen20048@gmail.com

${ }^{2}$ Chung Yuan Christian University (Department of Business Administration), Taiwan, rock@cycu.edu.tw
} 
the establishment of "Angel Venture Fund", "Taiwan Silicon Valley Science and Technology Fund", and the introduction of "Entrepreneurial Specialists". However, these policies generate little impact on increasing the employment rate. Therefore, it is particularly important to analyze and discuss the employment and entrepreneurship of Taiwanese.

On the contrary, although the economic development of mainland China has been affected by the international economic crisis as well, the economic development still maintains the trend of medium and high speed. In 2014, mainland China put forward the concept of "Widespread Entrepreneurship and Innovation" for the first time, and then few relative policies were formulated to encourage entrepreneurship. Furthermore, the mainland government not only encourages and promotes the entrepreneurship for residents in mainland China, but also actively attracts Taiwanese to enter the mainland for entrepreneurship and employment. In August 2015, Chinese government proposed to offer jobs to Taiwanese in order to exert their talents in the National People's Congress and the Chinese Political Consultative Conference. In 2016, the Fujian provincial government issued policies on encouraging and supporting Taiwanese to start businesses and obtain employment in Fujian, which is the first province to introduce relative policies to encourage Taiwanese to "landing" for businesses. Moreover, in 2018, the National Taiwan Office and the National Development and Reform Commission jointly issued the Measurements to Promote Cross-Strait Economic and Cultural Exchange and Cooperation, including 31 specific preferential policies, to provide equal treatment for Taiwanese to study, live, work, and start up in the mainland China. Based on the aforementioned, working or starting up in mainland China provided another option for Taiwanese under the circumstance of international economic crisis.

By reviewing of previous studies, some scholars had paid great attention to the issues related to the employment and entrepreneurial intention of Taiwanese in mainland China. First of all, according to (Huang and Lin, 2019; Liuet al., 2019; Sheng 2018), Taiwanese have high willingness to go to mainland China for employment and entrepreneurship. Meanwhile, the government also welcomes and attracts Taiwanese by proposing preferential policies to come to the mainland for employment and entrepreneurship. Nevertheless, the Taiwanese's intention to work or start-up in mainland China was affected by many factors. (Deng et al., 2018)discussed the attractive and obstructive factors that affect the intention of Taiwanese to go to the mainland for employment and entrepreneurship. The studies of both (Liu et al.,2019) and Tan (2018) pointed out that Taiwanese's intention of employment and entrepreneurship in mainland China was correlated to their cognition the mainland China. Some studies found that the relatives and friends became one of the important channels for Taiwanese to understand the mainland China, and affected the cognition of the mainland China as well (H. L. He et al., 2016; Liu et al., 2017).As can be found from previous studies, the attractive factors, obstructive factors, the relationship of relatives and friends, and the recognition of mainland China were a sort of determinants that affected the Taiwanese's intention for employment and entrepreneurship in mainland China. It is noteworthy that previous studies mainly concentrated on the impact of single influencing factors on employment and entrepreneurial intention by using correlation analysis and multiple regression analysis. However, attractive factors, 
obstructive factors and other dimensions contain several questions, the use of correlation analysis and multiple regression analysis cannot accurately find out the relationship between the two groups of variables. Therefore, on the basis of previous studies, this paper analyzes the direct impact of attractive factors, obstructive factors, the relationship of relatives and friends, personal characteristics, and the recognition of mainland China on Taiwanese's intention for employment and entrepreneurship by using questionnaire survey. Besides, in order to overcomes the limitations in correlation analysis and multiple regression analysis, this paper applied canonical correlation analysis to analyze the relationship between different dimensions, which can fully reveal the impact of determinants on Taiwanese's intention for employment and entrepreneurship in mainland China.

The remainder of this paper is organized as follows: Section 2 reviews literature related to this research, and proposed the hypothesis. Section 3 provides the empirical analysis of the determinants of the intention for employment and entrepreneurship in mainland China. Section 4 presents the conclusions and the suggestions of this study.

\section{LITERATURE REVIEW}

\subsection{Attractive factors}

Demographers frequently use "Push" and "Pull" to explain the international migration of labor force. In short, because it is not easy to earn a living in a place, part of the labor force has to move to an area where it is easier to earn a living, while a place where it is not easy to earn a living has virtually formed a "Push" force. On the other hand, an areas where it is easy to earn a living owing to more employment opportunities or higher salary, which generates a "Pull" force that attracts the international labor migration. The "Push" force belongs to the traction of the labor force, in other words, the area where is easy to earn a living attracts the labor force. The factors that have led Taiwanese to choose to work and start businesses in the mainland China are the attractive factors.

Among the many attractive factors, economic development are one of the important factors attract Taiwanese to employment and entrepreneurship in mainland China. In recent years, affected by the global financial crisis, the speed of economic development has slowed down. Despite this, economic development in mainland China it still maintains a good and stable growth trend. As a result of sustained and stable economic growth, and more employment and entrepreneurship opportunities become the important factors to attract Taiwanese to work or start-up in mainland China (Deng et al., 2018). The huge economic development potential of mainland China and its increasing economic influence attracted more and more Taiwanese willing to westward and devote themselves to the economic construction of mainland China (Liu et al., 2019).

Additionally, searching for a wider market is another important factor in attracting Taiwanese to the mainland China (Deng et al., 2018). Few decades ago, Taiwan companies invested in the mainland China mainly because of the rich and cheap labor force. With the economic 
development and national income increasing in mainland China, lots of Taiwan companies no longer confine their vision to the global market, but pay more attention to the market in mainland China, focusing on meeting the consumption demand of mainland China (Lin, 2018).

The gap of wage between cross-strait is the other factor attracting Taiwanese for employment and entrepreneurship in mainland China. Liu et al. (2017)pointed out that the pursuit of high salary, high position and higher professional vision were the motivation for Taiwanese to work in mainland China. Yu (2005)also pointed out that expatriate compensation and recognition of fairness of compensation have positive effects on satisfaction of compensation and willingness for expatriate managers.

According to the literature review, due to restrictions imposed by Taiwan's laws and regulations, some start-up teams or enterprises have to choose to start a business in mainland China(Liu et al., 2019). On the contrary, the government in mainland China actively encourages and promotes entrepreneurship through preferential tax policies and simplified business registration process. Furthermore, there are many incubators and accelerators set up by government or non-governmental organizations to further promote entrepreneurship, which undoubtedly can be treated as a "Pull" force to attract Taiwanese to start business in the mainland China (Guo \& Chen, 2018).

\subsection{Obstructive factors}

The rapid economic development and the vast domestic market in mainland China are the attractive factors to Taiwanese for employment and entrepreneurship. However, due to the complicated political relationship between cross strait, Taiwanese people's lack of understanding and even cognitive errors will hinder Taiwanese people from going to the mainland for employment and entrepreneurship.

Tan (2018)analyzed the problems encountered by young people of Taiwan in their employment and entrepreneurship using questionnaire survey, and concluded that personal accomplishment, political management, social atmosphere and differences between cross strait have negative effect on intention of employment and entrepreneurship in mainland China. In addition, the differences in online marketing methods, consumption habits and business habits in the mainland also hinder Taiwanese from going to the mainland to employment and entrepreneurship(Deng et al., 2018).

Unknown about the mainland China is also one of the obstacles to employment and entrepreneurship of Taiwanese, including the preferential policies, the relative laws and regulations, and the transportation system, etc. Because of the "petty happiness" characteristics, Taiwanese pay more attention to their own and internal affairs, while unconcerned about political activities and external events (Liu et al., 2017). Hence, they do not really have a deep understanding of the mainland China.

Besides, worries about personal and property security, lack of contacts, partnerships, clients 
and relationships, personal maladjustment, and lack of cross-cultural communication skills in mainland China are also important factors hindering Taiwanese from going to the mainland for employment and entrepreneurship(Liu \& Chen, 2018; Liu et al., 2019; Xie, 2018).

\subsection{Relationship of relatives and friends}

Herring and Butler (1991)found that if parents start their own businesses, their behavior would instill in their children the concept of self-achievement. Thus, children will be inspired by their entrepreneurial practice, which has a significant effect on entrepreneurial intention. Except for the parents, family environment or other people who are important to personal growth, such as spouse, teachers, friends, classmates and countrymen, will affect the entrepreneurial intention and motivation(Aslam et al., 2012). Researcher Lee (2013) summed up all the relatives and friends that affect entrepreneurial intention as family environment, and believed that personal factors, parents' socioeconomic status, whether the family has a business background, family members' support, parents' social status, family structure and family atmosphere will all affect entrepreneurial intention and behavior.

(Wang et al., 2010)found that family members own entrepreneurial experience and relevant resources such as money, contacts and relation could enhance the self-efficacy of entrepreneurs. Supporting from family members, friends and other relatives and friends may have a profound impact on career choices. Specifically, entrepreneurial intention will be enhanced by getting spiritual and financial support from family member, friends and relatives (Turker \& Selcuk, 2009). According to the previous studies, Taiwanese stated that having relatives or friends working or starting businesses in the mainland China had a positive impact on their employment and entrepreneurial intention (Deng et al., 2018). However, some studies revealed that negative cognition affects the intention of Taiwanese for employment and entrepreneurship in mainland China(Sheng, 2018).

By reviewing, it can be found that the impact of relatives and friends mainly focuses on entrepreneurship, rather than on employment. Therefore, this paper will pay great attention on discussing the impact of relatives and friends on employment.

\subsection{Personal characteristics}

The personal characteristic is mainly to explore the potential ability of an individual who will work in other place. Employment and entrepreneurship in mainland China are faced with leaving the comfort zone and entering a relatively unfamiliar social environment. Apart from the professional skills and language skills required for overseas work, acquiring the relationships in overseas society and the ability to adapt to cultural differences and pressures of overseas life are all important conditions for judging whether they have the ability to go to the mainland China for employment and entrepreneurship(Tsai, 2011).

In psychology, five personality trait models are often used to describe the scope and aspects of personality, namely, openness to experience, conscientiousness, extroversion, affinity and emotional instability. Empirical openness is oriented to the view that people with experience 
openness are generally eager to explore, curious, creative and willing to try new things; conscientious marking tends to be self-disciplined, aiming at achieving measures or external expectations; higher conscientiousness shows their preference for planning rather than unconscious behavior; and It is characterized by significant participation with the outside world, like to communicate, full of vitality; affinity people are easy to get along with others, have good team cooperation skills; emotional instability is more likely to experience negative emotions, and is regarded as low stress tolerance and delayed stimulation. Generally speaking, Taiwanese with high experience, openness, conscientiousness, extroversion and affinity, and stable emotions will have higher willingness to go to the mainland for employment and entrepreneurship (Li et al., 2013).

Based on the research of cultivating cross-cultural expatriates in high-tech industries, Zhuang (2008) believed that professional competence, interpersonal relationship, communication skills, coordination ability and open mind are important factors affecting the development of expatriates to the mainland China. Researcher Lan (2001)took employees fromTaiwan's 1,000 largest enterprises as the object and found that the ability of expatriates is significantly related to overseas adaptation. Specifically, expatriates should have the ability to deal with psychological pressure, communicate, establish relationships, perceive cross-cultures, and have cultural empathy.

\subsection{Cognition to mainland China}

Generally, the previous studies believed that the lack of understanding of the mainland China results in cognitive bias, which leads to feelings of rejection or even resistance for Taiwanese to studying, working and living in the mainland China. Deng et al. (2018)also found that the Taiwan youth lack of exchanges between cross-strait, which result in the unfamiliar with mainland China. With the deepening of cross-strait communication and the popularization of the Internet, more and more young people are getting to know the mainland through various channels. Tan (2018)found that most of interviewees have a high degree of recognition of the mainland China from the results of questionnaire survey. However, Liu and Li (2016) stated that the negative "impression of mainland China" exists at the same time as positive "entrepreneurial intention".

Based on the review, discussing the impact of the cognition of the mainland China on Taiwanese employment and entrepreneurship has become another focus of this paper.

\subsection{Purpose and hypothesis}

Because of the cognitive bias, difference in social and cultural, Taiwanese are less receptive to the mainland China. Therefore, this paper focuses on the impact of cognition of mainland China on the Taiwanese's intention for employment and entrepreneurship. Other influencing factors, including attractive factors, obstructive factors, the relationship with relatives and friends, and personal characteristics, not only affect the employment and entrepreneurial intention, but also the affect the cognition of mainland China. Hence, the impact of all the influencing factors on Taiwanese's intention for employment and entrepreneurship in mainland China, as well as the 
relationship between factors, will be fully discussed in this paper. The theoretical framework of this study has developed the following research assumptions based on past literature research, which are described below.

The environment of employment and entrepreneurship is uncontrollable(Lianget al., 2019). However, the environment of employment and entrepreneurship has a significant impact on the success and failure of enterprises. Moreover, the employment and entrepreneurship environment is the most important factor that causes the differences in entrepreneurial activities in different countries (Esfandiar et al., 2019). The most important feature of the environment is its uncertainty. The uncertainty of the entrepreneurial environment may come from the external or internal of the enterprise. The commercial opportunity can be pursuit only in an uncertain environment. On the contrary, the uncertainty of the environment will also have a negative impact on employment and entrepreneurship. Therefore, this paper divides the employment and entrepreneurship environment into attractive factors and obstructive factors to analyze the impact on Taiwanese's cognition of mainland China. More specifically, attractive factors, such as vast domestic market, more job and entrepreneurialopportunities, stable economic growth, and preferential policies, increase Taiwanese's recognition of the mainland China. On the contrary, great working pressure, fierce competition, social and cultural differences, and other obstructive factors have a negative impact on the impression of the mainland China.

H1: The attractive factors have positive effect on the cognition of mainland China.

H2: The obstructive factors have negative effect on the cognition of mainland China.

Because of the cheap labor force and the vast domestic market, the mainland China has always been one of the main destinations for Taiwan's enterprises to invest abroad. Many enterprises invest in the mainland and set up factories, which caused a deep understanding of the economic, social and cultural development.

Due to political reasons, cross-strait communication and exchanges are often limited, resulting in Taiwanese unfamiliar or misunderstand the current situation of the mainland China. However, with the increase of cross-strait exchanges and cooperation, lots of Taiwanese have come to work and live in the mainland in recent years. These people have a general understanding of the development circumstance in mainland China, which can provide advice for new entrants and avoid taking fewer detours. Therefore,obtaining accurate information about the mainland China from the relatives and friends who have already worked or started up is helpful to correct cognition of mainland China, and finally enhance the intention of employment and entrepreneurship.

H3: The relationships of relatives and friends have positive effect on the cognition of mainland China.

Allport (1966) believed that people's core characteristics determine the stability of their behavior, including achievement needs, risk tendencies, internal control sources and tolerance of ambiguity. Having a high degree of extroversion and openness in one's personal characteristics will help to improve one's acceptance of different things. Based on the above 
analysis, this paper concludes that personal characteristics have a positive impact on the Taiwanese's cognition of mainland China.

H4: The personal characteristics affect the cognition to mainland China

Seeking a vast domestic market is one of the main reasons for Taiwanese to work and start up in mainland China. Based on the reviewing, the results of the influence of the relatives and friends on intention of employment and entrepreneurship does not reach consensus. However, previous studies found that having relatives and friends working or starting up in mainland China could help them better understanding the current status of economic development, preferential policies, and also reducing their worries about the possible risks of employment and entrepreneurship in mainland China (Deng et al., 2018). Therefore, this study infers that the relationship between attractive factors, obstructive factors and the cognition of mainland China will be affected by the relationship of relatives and friends.

H51: The relationship of relatives and friends affect the relationship between the attractive factors and the cognition of mainland China.

H52: The relationship of relatives and friends affect the relationship between the obstructive factors and the cognition of mainland China.

Previous studies found that entrepreneurs have unique psychological characteristics, including achievement needs, risk-taking, self-efficacy, internal control ability, and tolerance for ambiguity. These psychological characteristics determine that entrepreneurs are superior to others in opportunity identification. Entrepreneurs with these characteristics often respond positively to all uncertainties. They are more willing to take risks and can control their own behavior. The characteristics of employer and entrepreneurs will be easier to identify the strengths and weaknesses of employment and entrepreneurship in mainland China, and then affect their cognition of mainland China. Therefore, this paper believes that the relationship between attractive factors, obstructive factors and the cognition of mainland China will be affected by personal characteristics.

H61: The personal characteristics affect the relationship between the attractive factors and the cognition of mainland China.

H62: The personal characteristics affect the relationship between the obstructive factors and the cognition of mainland China.

There are differences in politics, culture, social system and lifestyle between cross strait, which cause some difficulties for Taiwanese to go to the mainland China for employment or entrepreneurship. However, many Taiwanese indicated that they can take the initiative to adapt to the cultural environment of mainland China. Previous studies also presented that the better understanding of the mainland and the acceptance of the differences between cross strait, the stronger the intention to go to the mainland for employment and entrepreneurship (Liu \& $\mathrm{Li}$, 2016; Liu et al., 2017). Therefore, this paper believed that the increase in cognition of mainland China has a positive impact on intention of Taiwanese for employment and entrepreneurship in mainland China. 
H7: The cognition of mainland China affects the intention of employment and entrepreneurship.

Based on the analysis above, the research framework is as follows:

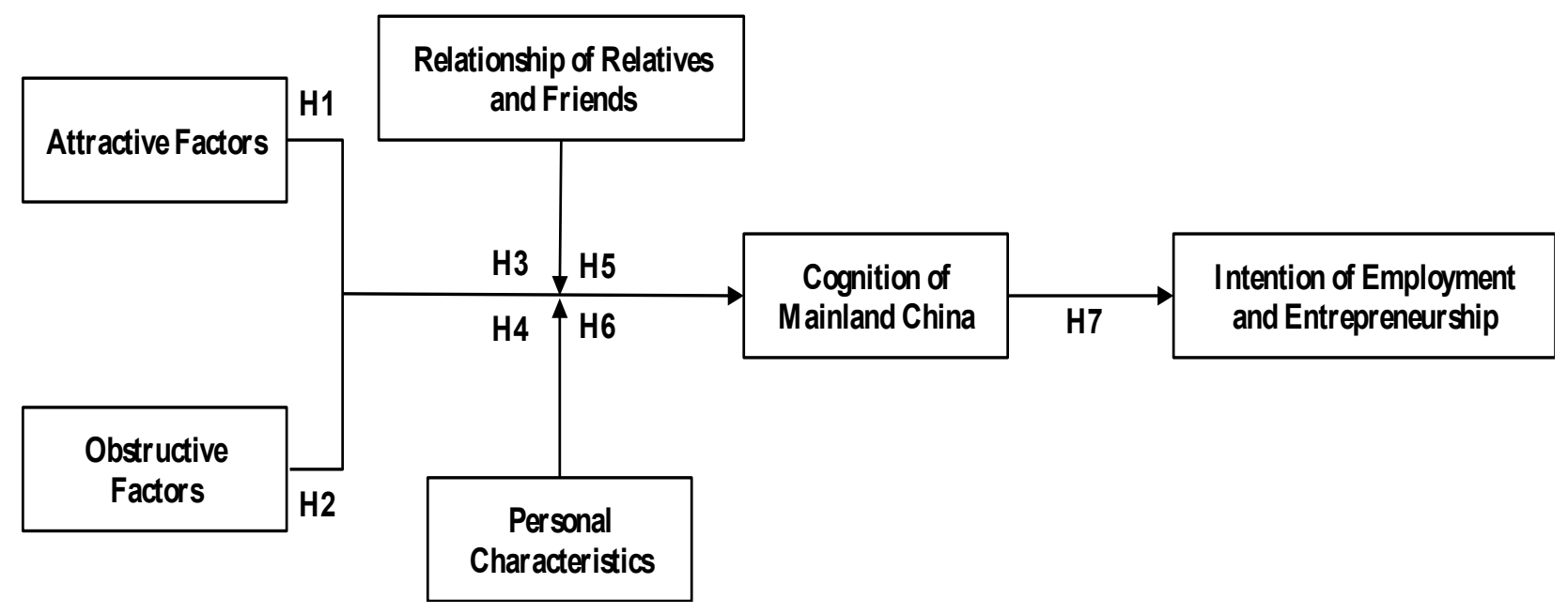

Figure 1. Research framework

\section{EMPIRICAL RESULTS}

In order to understand the current situation, development and problems of employment and entrepreneurship in mainland China, this paper conducted a questionnaire survey in Taiwan and mainland China. A total of 590 responses were distributed, and 568 responses were obtained.

\subsection{Descriptive statistics}

The descriptive statistics are presented in Table 1.

Table 1. Description Statistics

\begin{tabular}{|c|c|c|c|}
\hline \multirow{4}{*}{ Gender } & & Sample (People) & Percentage (\%) \\
\hline \multirow{4}{*}{ Education } & Male & 297 & $52.3 \%$ \\
\cline { 2 - 4 } & Female & 271 & $47.7 \%$ \\
\cline { 2 - 4 } & High school & 29 & 8.6 \\
\cline { 2 - 4 } & Bachelor & 349 & 61.4 \\
\hline \multirow{4}{*}{ Living area } & Master & 143 & 25.2 \\
\cline { 2 - 4 } & Ph.D. & 27 & 4.8 \\
\cline { 2 - 4 } & North & 433 & 76.2 \\
\cline { 2 - 4 } & Central & 57 & 10.0 \\
\hline \multirow{4}{*}{ Subjects } & South & 68 & 12.0 \\
\cline { 2 - 4 } & East & 10 & 1.8 \\
\cline { 2 - 4 } & Science & 120 & 4.8 \\
\cline { 2 - 4 } & Engineering & 199 & 21.1 \\
\hline
\end{tabular}




\begin{tabular}{|c|c|c|c|}
\hline & & Sample (People) & Percentage (\%) \\
\hline \multirow{4}{*}{ Architectural design } & 14 & 2.5 \\
\cline { 2 - 4 } & Humanistic education & 84 & 14.8 \\
\cline { 2 - 4 } & Social science & 23 & 4.0 \\
\cline { 2 - 4 } & Medicine and health & 23 & 4.0 \\
\cline { 2 - 4 } & Media & 15 & 2.6 \\
\cline { 2 - 4 } & Others & 63 & 11.1 \\
\hline
\end{tabular}

The intention of Taiwanese for employment and entrepreneurship in mainland China is presented in Table 2. As can be seen from the Table 2, most of Taiwanese have ordinary intention for employment and entrepreneurship in mainland China.

Table 2. Intention of Taiwanese for Employment and entrepreneurship intention in mainland China

\begin{tabular}{|c|c|c|c|c|c|}
\hline $\begin{array}{c}\text { Employment } \\
\text { intention }\end{array}$ & $\begin{array}{c}\text { Sample } \\
(\text { People) }\end{array}$ & $\begin{array}{c}\text { Percentage } \\
(\boldsymbol{\%})\end{array}$ & $\begin{array}{c}\text { Entrepreneurship } \\
\text { Intention }\end{array}$ & $\begin{array}{c}\text { Sample } \\
\text { (People) }\end{array}$ & $\begin{array}{c}\text { Percentage } \\
(\boldsymbol{\%})\end{array}$ \\
\hline Highly expectation & 54 & 9.5 & Highly expectation & 59 & 10.4 \\
\hline Expectation & 116 & 20.4 & Expectation & 121 & 21.3 \\
\hline Ordinary & 223 & 39.3 & Ordinary & 218 & 38.4 \\
\hline Low expectation & 96 & 16.9 & Low expectation & 96 & 16.9 \\
\hline Withoutconsideration & 70 & 13.9 & Withoutconsideration & 74 & 13.0 \\
\hline
\end{tabular}

\subsection{Factor analysis}

This paper used a questionnaire with 65 questions from the different dimensions of attractive factors, obstructive factors, the relationship of relatives and friends, personal characteristics, and the cognition of mainland China to analyses the intention of Taiwanese for employment and entrepreneurship. In general the items were measured by 5-point Likert scale, varying from 1 (highly unlikely) to 5 (totally agree). Because there are many questions in each dimension, the factor analysis method is used to extract and name the questions before the correlation analysis between the influencing factors and the willingness to go to the mainland for employment and entrepreneurship. The results of factor analysis are shown in Table 3. According to the Table 3.

The attractive factors can extract the supporting service and the preferential policy, which means that the supporting service and preferential policy are the important factor for employment and entrepreneurship. The obstructive factors can extract from the poor environment, maladjustment and competitive pressure. In other words, the social and cultural differences between cross-strait, unable to adapt to the social environment, and the greater competitive pressure are the major factor obstructed the Taiwanese for employment and entrepreneurship in mainland China. The relationship of relatives and friends can extract the experience and encouragement. Getting the support and encouragement from relatives and friends who have already been working or starting up in mainland China will affect the intention of Taiwanese for employment and entrepreneurship. The personal characteristics 
include core competence and international concept. The Taiwanese with strong competence and international concept will have stronger intention for employment and entrepreneurship in mainland China. The dimension of cognition of mainland China can extract identify with mainland China and familiar with mainland China. Both recognition and better understanding of mainland China are important influential factors for Taiwanese to choose whether work or start up in mainland China.

Table 3.Factor analysis of different dimensions

\begin{tabular}{|c|c|c|c|}
\hline Dimension & Questions & Loading & Factor \\
\hline \multirow{15}{*}{$\begin{array}{l}\text { Attractive } \\
\text { factors }\end{array}$} & $\begin{array}{l}\text { Government creates a good environment for employment } \\
\text { and entrepreneurship. }\end{array}$ & 0.62 & \multirow{7}{*}{$\begin{array}{l}\text { Supporting } \\
\text { services }\end{array}$} \\
\hline & $\begin{array}{l}\text { Taiwanese's commercial guilds assist or provide } \\
\text { consultation in mainland China }\end{array}$ & 0.68 & \\
\hline & $\begin{array}{l}\text { Providing housing security, employment and } \\
\text { entrepreneurship assistance. }\end{array}$ & 0.69 & \\
\hline & $\begin{array}{l}\text { Familiar with welfare and promotion system in mainland } \\
\text { China. }\end{array}$ & 0.82 & \\
\hline & $\begin{array}{l}\text { Abundant funds and perfect tutoring measures in mainland } \\
\text { China. }\end{array}$ & 0.80 & \\
\hline & Perfect construction of industrial chain in mainland China. & 0.85 & \\
\hline & $\begin{array}{l}\text { Well legal system and government efficiency in mainland } \\
\text { China }\end{array}$ & 0.81 & \\
\hline & Lager domestic market in mainland China. & 0.74 & \multirow{8}{*}{$\begin{array}{l}\text { Preferential } \\
\text { policy }\end{array}$} \\
\hline & More development opportunity in mainland China. & 0.78 & \\
\hline & Higher basic salary in mainland China. & 0.50 & \\
\hline & Faster and higher range in salary in mainland China. & 0.67 & \\
\hline & $\begin{array}{l}\text { Launching relative policy to encourage Taiwanese for } \\
\text { employment and entrepreneurship in mainland China. }\end{array}$ & 0.61 & \\
\hline & $\begin{array}{l}\text { Having self-realization and self-development opportunities } \\
\text { in mainland China. }\end{array}$ & 0.60 & \\
\hline & Learning world-class enterprise talents in mainland China. & 0.62 & \\
\hline & Getting international perspective & 0.56 & \\
\hline \multirow{10}{*}{$\begin{array}{l}\text { Obstructive } \\
\text { factors }\end{array}$} & Mainland China frequently oppresses Taiwan. & 0.70 & \multirow{10}{*}{$\begin{array}{l}\text { Poor } \\
\text { environment }\end{array}$} \\
\hline & Non-democracy of the political system in mainland China. & 0.77 & \\
\hline & Dislike the social atmosphere in mainland China. & 0.74 & \\
\hline & Serious corruption in mainland China. & 0.77 & \\
\hline & Outstanding preferential policy in mainland China. & 0.78 & \\
\hline & Worry about personal security. & 0.69 & \\
\hline & Uncivilized behavior in mainland China. & 0.69 & \\
\hline & Poor health environment and medical conditions. & 0.62 & \\
\hline & Differences in values between cross strait. & 0.58 & \\
\hline & Salary and welfare in mainland China did not meet & 0.54 & \\
\hline
\end{tabular}




\begin{tabular}{|c|c|c|c|}
\hline Dimension & Questions & Loading & Factor \\
\hline & expectation. & & \\
\hline & Failure cases of Taiwanese in mainland China. & 0.54 & \\
\hline & $\begin{array}{l}\text { Unfamiliar with market and working environment in } \\
\text { mainland China. }\end{array}$ & 0.58 & \multirow{6}{*}{ Maladjustment } \\
\hline & Great working pressure in mainland China. & 0.57 & \\
\hline & Most of relatives and friends stay in Taiwan. & 0.61 & \\
\hline & Can't leave Taiwan's comfort zone. & 0.73 & \\
\hline & Not adapt to food, life and weather in mainland China. & 0.64 & \\
\hline & Fettered by parents, girlfriend/boyfriend or children & 0.53 & \\
\hline & Greater competitive pressure in mainland China. & 0.81 & \multirow[b]{2}{*}{$\begin{array}{l}\text { Competitive } \\
\text { pressure }\end{array}$} \\
\hline & $\begin{array}{l}\text { Difficult to return to Taiwan after going to the mainland } \\
\text { China for employment and entrepreneurship. }\end{array}$ & 0.53 & \\
\hline \multirow{10}{*}{$\begin{array}{l}\text { Relationship } \\
\text { of relatives } \\
\text { and Friends }\end{array}$} & $\begin{array}{l}\text { Successful employment and entrepreneurship experiences in } \\
\text { mainland China from family members or relatives. }\end{array}$ & 0.64 & \multirow{6}{*}{ Experience } \\
\hline & $\begin{array}{l}\text { Successful employment and entrepreneurship experiences in } \\
\text { mainland China from classmates or friends. }\end{array}$ & 0.72 & \\
\hline & $\begin{array}{l}\text { Many family members or relatives agree with the statement } \\
\text { "People on both sides of the Taiwan Straits are all of one } \\
\text { family". }\end{array}$ & 0.78 & \\
\hline & $\begin{array}{l}\text { Many classmates or friends agree with the statement "People } \\
\text { on both sides of the Taiwan Straits are all of one family". }\end{array}$ & 0.78 & \\
\hline & $\begin{array}{l}\text { Family members or relatives have the ability to introduce } \\
\text { you to mainland China for employment or entrepreneurship. }\end{array}$ & 0.76 & \\
\hline & $\begin{array}{l}\text { Classmates or friends have the ability to introduce you to the } \\
\text { mainland China for employment or entrepreneurship. }\end{array}$ & 0.78 & \\
\hline & $\begin{array}{l}\text { Support and encouragement from Girlfriend/Boyfriend and } \\
\text { spouse for Employment and Entrepreneurship. }\end{array}$ & 0.72 & \multirow{4}{*}{ Encourą } \\
\hline & $\begin{array}{l}\text { Support and Encouragement from parents for employment } \\
\text { and entrepreneurship. }\end{array}$ & 0.87 & \\
\hline & $\begin{array}{l}\text { Support and encourage from relatives for employment and } \\
\text { entrepreneurship. }\end{array}$ & 0.84 & \\
\hline & $\begin{array}{l}\text { Support and encourage from classmates and friends for } \\
\text { employment and entrepreneurship. }\end{array}$ & 0.73 & \\
\hline \multirow{7}{*}{$\begin{array}{c}\text { Personal } \\
\text { Characteristics }\end{array}$} & Having clear career planning. & 0.66 & \multirow{7}{*}{$\begin{array}{c}\text { Core } \\
\text { competence }\end{array}$} \\
\hline & Quickly adapt to the new working environment. & 0.75 & \\
\hline & Persistence when facing setbacks & 0.76 & \\
\hline & Frequently put forward the idea of innovation and creation. & 0.76 & \\
\hline & I got capable of working. & 0.81 & \\
\hline & I got ambitious. & 0.83 & \\
\hline & I got aggressive. & 0.83 & \\
\hline
\end{tabular}




\begin{tabular}{|c|c|c|c|}
\hline Dimension & Questions & Loading & Factor \\
\hline & I am attractive & 0.84 & \\
\hline & I am active in the group. & 0.76 & \\
\hline & Love to know customs and people all over the world. & 0.92 & \multirow{2}{*}{$\begin{array}{l}\text { International } \\
\text { perspective }\end{array}$} \\
\hline & Love to travel and get in touch with local people. & 0.91 & \\
\hline \multirow{10}{*}{$\begin{array}{c}\text { Cognition of } \\
\text { mainland } \\
\text { China }\end{array}$} & $\begin{array}{l}\text { Centralized system in mainland China makes policy } \\
\text { promotion more effective. }\end{array}$ & 0.66 & \multirow{6}{*}{$\begin{array}{c}\text { Identify with } \\
\text { mainland } \\
\text { China }\end{array}$} \\
\hline & Mainland China has been transformed to a legal country. & 0.77 & \\
\hline & Improved in uncivilized behavior. & 0.73 & \\
\hline & Well infrastructural construction in mainland China. & 0.57 & \\
\hline & $\begin{array}{l}\text { Agree with "People on both sides of the Taiwan Straits are } \\
\text { all of one family". }\end{array}$ & 0.77 & \\
\hline & I am both Taiwanese and Chinese & 0.78 & \\
\hline & $\begin{array}{l}\text { Love to know the geography and knowledge of the mainland } \\
\text { China. }\end{array}$ & 0.85 & \\
\hline & Love to travel to mainland China. & 0.83 & Illar with \\
\hline & Love to understand Chinese culture and people's feelings. & 0.86 & China \\
\hline & $\begin{array}{l}\text { Reading books and absorbing relevant information about } \\
\text { mainland China. }\end{array}$ & 0.69 & \\
\hline
\end{tabular}

\subsection{Correlation analysis}

In order to understand the correlation between each factor and intention of employment and entrepreneurship, this paper firstly applied correlation analysis to analyze the correlation between each factor and intention of Taiwanese for employment and entrepreneurship in mainland China. The results of correlation analysis are shown in Table 4.

As can be seen from table 4, there is a significant positive correlation between attractive factors, the relationship of relatives and friends, cognition of mainland China and intention of employment and entrepreneurship. Specifically, implementing supporting service and preferential policy will have positive attractive effect on intention of Taiwanese for employment and entrepreneurship in mainland China. Meanwhile, with support and encouragement from relatives and friends will strength the cognition of mainland China, and thus strength the intention of employment and entrepreneurship. The poor environment and maladjustment are significant negatively related to intention of employment and entrepreneurship. The core competence in the dimension of personal characteristics is significantly positively correlated with the intention of employment and entrepreneurship, which indicates that Taiwanese with strong core competence are more willing to employment and entrepreneurship in mainland China. 
Table 4. Correlation analysis

\begin{tabular}{|c|c|c|c|c|c|c|c|c|c|c|c|c|c|}
\hline & 1 & 2 & 3 & 4 & 5 & 6 & 7 & 8 & 9 & 10 & 11 & 12 & 13 \\
\hline $\begin{array}{c}1 \text { Supporting } \\
\text { service }\end{array}$ & 1.00 & - & - & - & - & - & - & - & - & - & - & - & - \\
\hline $\begin{array}{l}2 \text { Preferential } \\
\text { policy }\end{array}$ & $0.68^{* * * *}$ & 1.00 & - & - & - & - & - & - & - & - & - & - & - \\
\hline $\begin{array}{c}3 \text { Poor } \\
\text { environment }\end{array}$ & $\begin{array}{c}-0.34^{* *} \\
*\end{array}$ & $\begin{array}{c}-.026^{* *} \\
*\end{array}$ & 1.00 & - & - & - & - & - & - & - & - & - & - \\
\hline $\begin{array}{c}4 \\
\text { Maladjustment }\end{array}$ & -.003 & -0.04 & $0.53^{* * *}$ & 1.00 & - & - & - & - & - & - & - & - & - \\
\hline $\begin{array}{c}5 \text { Competence } \\
\text { pressure }\end{array}$ & .017 & $0.14^{* * *}$ & $0.45^{* * *}$ & $0.42^{* * *}$ & 1.00 & - & - & - & - & - & - & - & - \\
\hline 6 Experience & $0.46^{* * *}$ & $0.42^{* * *}$ & $\begin{array}{c}-0.33^{* *} \\
*\end{array}$ & $\begin{array}{c}-0.16^{* *} \\
*\end{array}$ & -0.04 & 1.00 & - & - & - & - & - & - & - \\
\hline $\begin{array}{c}7 \\
\text { Encouragement }\end{array}$ & $0.50^{* * * *}$ & $0.84^{* * *}$ & $\begin{array}{c}-0.18^{* *} \\
*\end{array}$ & -0.04 & $\begin{array}{c}0.15^{* *} \\
*\end{array}$ & $\begin{array}{c}0.26^{* *} \\
*\end{array}$ & 1.00 & - & - & - & - & - & - \\
\hline $\begin{array}{c}8 \text { Core } \\
\text { Competence }\end{array}$ & $0.24^{* * *}$ & $0.31^{* * *}$ & $\begin{array}{c}-0.13^{* *} \\
*\end{array}$ & $\begin{array}{c}-0.26^{* *} \\
*\end{array}$ & 0.03 & $\begin{array}{c}0.33^{* *} \\
*\end{array}$ & $\begin{array}{c}0.23^{* *} \\
*\end{array}$ & 1.00 & - & - & - & - & - \\
\hline $\begin{array}{c}9 \text { International } \\
\text { perspective }\end{array}$ & $0.14^{* * * *}$ & $0.27^{* * * *}$ & -0.01 & -0.04 & $\begin{array}{c}0.13^{* *} \\
*\end{array}$ & $\begin{array}{c}0.17^{* *} \\
*\end{array}$ & $\begin{array}{c}0.25^{* *} \\
*\end{array}$ & $\begin{array}{c}0.47^{* *} \\
*\end{array}$ & 1.00 & - & - & - & - \\
\hline $\begin{array}{l}10 \text { Identify with } \\
\text { mainland China }\end{array}$ & $.050^{* * * *}$ & $0.55^{* * *}$ & $\begin{array}{c}-0.57^{* *} \\
*\end{array}$ & $\begin{array}{c}-0.23^{* *} \\
*\end{array}$ & $\begin{array}{c}-0.09^{*} \\
*\end{array}$ & $\begin{array}{c}0.56^{* *} \\
*\end{array}$ & $\begin{array}{c}0.40^{* *} \\
*\end{array}$ & $\begin{array}{c}0.34^{* *} \\
*\end{array}$ & $\begin{array}{c}0.24^{* *} \\
*\end{array}$ & 1.00 & - & - & - \\
\hline $\begin{array}{c}11 \text { Familiar } \\
\text { with mainland } \\
\text { China }\end{array}$ & $0.32^{* * * *}$ & $0.40^{* * * *}$ & $\begin{array}{c}-0.32^{* *} \\
*\end{array}$ & $\begin{array}{c}-0.26^{* *} \\
*\end{array}$ & -0.06 & $\begin{array}{c}0.47^{* *} \\
*\end{array}$ & $\begin{array}{c}0.26^{* *} \\
*\end{array}$ & $\begin{array}{c}0.48^{* *} \\
*\end{array}$ & $\begin{array}{c}0.40^{* * *} \\
*\end{array}$ & $\begin{array}{c}0.61^{* *} \\
*\end{array}$ & 1.00 & - & - \\
\hline $\begin{array}{c}\text { 12Employment } \\
\text { intention }\end{array}$ & $0.17^{* * * *}$ & $0.23^{* * * *}$ & $\begin{array}{c}-0.17^{* *} \\
*\end{array}$ & $\begin{array}{c}-0.14^{* *} \\
*\end{array}$ & -0.02 & $\begin{array}{c}0.21^{* *} \\
*\end{array}$ & $\begin{array}{c}0.17^{* *} \\
*\end{array}$ & $\begin{array}{c}0.16^{* *} \\
*\end{array}$ & 0.07 & $\begin{array}{c}0.21^{* *} \\
*\end{array}$ & $\begin{array}{c}0.20^{* * *} \\
*\end{array}$ & 1.00 & - \\
\hline $\begin{array}{c}13 \\
\text { Entrepreneursh } \\
\text { ip intentions }\end{array}$ & $0.17^{* * * *}$ & $0.21^{* * *}$ & $\begin{array}{c}-0.21^{* *} \\
*\end{array}$ & $\begin{array}{c}-0.18^{* *} \\
*\end{array}$ & -0.06 & $\begin{array}{c}0.23^{* *} \\
*\end{array}$ & $\begin{array}{c}0.16^{* *} \\
*\end{array}$ & $0.11^{* *}$ & 0.03 & $\begin{array}{c}0.19^{* *} \\
*\end{array}$ & $\begin{array}{c}0.15^{* *} \\
*\end{array}$ & $\begin{array}{c}0.82^{* *} \\
*\end{array}$ & $\begin{array}{c}1.0 \\
0\end{array}$ \\
\hline
\end{tabular}

Note: ${ }^{*} \mathrm{p}<0.1,{ }^{* *} \mathrm{p}<0.05,{ }^{* * *} \mathrm{p}<0.01$

\subsection{Canonical correlation analysis}

After correlation analysis between factors and intention of Taiwanese for employment and entrepreneurship in mainland China, this paper further conducts canonical correlation analysis on two groups of research perspectives to test the hypothesis aforementioned. The results of canonical correlation analysis are shown in Table 5. 
Table 5.Results of canonical correlation analysis

\begin{tabular}{|c|c|c|c|c|c|}
\hline Hypothesis & Dimension one & Dimension two & $\begin{array}{l}\text { Canonical } \\
\text { correlation }\end{array}$ & Wilk's & Results \\
\hline $\mathrm{H} 1$ & Attractive factor & $\begin{array}{c}\text { Cognition of } \\
\text { mainland China }\end{array}$ & 0.58 & $0.66^{* * *}$ & Supported \\
\hline $\mathrm{H} 2$ & Obstructive factor & $\begin{array}{l}\text { Cognition of } \\
\text { mainland China }\end{array}$ & 0.61 & $0.61^{* * *}$ & Supported \\
\hline H3 & $\begin{array}{c}\text { Relationship of relatives } \\
\text { and friends }\end{array}$ & $\begin{array}{l}\text { Cognition of } \\
\text { mainland China }\end{array}$ & 0.63 & $0.60^{* * *}$ & Supported \\
\hline $\mathrm{H} 4$ & Personal characteristics & $\begin{array}{l}\text { Cognition of } \\
\text { mainland China }\end{array}$ & 0.52 & $0.73^{* * *}$ & Supported \\
\hline H51 & $\begin{array}{c}\text { Attractive factor \& } \\
\text { Relationship of relatives } \\
\text { and friends }\end{array}$ & $\begin{array}{l}\text { Cognition of } \\
\text { mainland China }\end{array}$ & 0.68 & $0.53^{* * *}$ & Supported \\
\hline H52 & $\begin{array}{c}\text { Attractive factor \& } \\
\text { Personal characteristics }\end{array}$ & $\begin{array}{l}\text { Cognition of } \\
\text { mainland China }\end{array}$ & 0.63 & $0.53^{* * *}$ & Supported \\
\hline H61 & $\begin{array}{c}\text { Obstructive factor \& } \\
\text { Relationship of relatives } \\
\text { and friends }\end{array}$ & $\begin{array}{l}\text { Cognition of } \\
\text { mainland China }\end{array}$ & 0.74 & $0.42^{* * *}$ & Supported \\
\hline H62 & $\begin{array}{l}\text { Obstructive factor \& } \\
\text { personal characteristics }\end{array}$ & $\begin{array}{l}\text { Cognition of } \\
\text { mainland China }\end{array}$ & 0.68 & $0.50^{* * *}$ & Supported \\
\hline $\mathrm{H} 7$ & $\begin{array}{c}\text { Cognition of mainland } \\
\text { China }\end{array}$ & $\begin{array}{l}\text { Intention of } \\
\text { employment and } \\
\text { entrepreneurship }\end{array}$ & 0.23 & $0.95^{* * *}$ & Supported \\
\hline
\end{tabular}

As can be seen from Table 5, the results of canonical correlation analysis indicated that the coefficients of canonical correlation are significant, thus the research framework of this paper is fully supported by empirical study. Specifically, the coefficients of canonical correlation are increased after introducing interference variables, personal characteristics and relationships of relatives and friends, into the analysis between attractive factors and cognition of mainland China. Similarly, the coefficients of canonical correlation are increased after introducing interference variables, personal characteristics and relationships of relatives and friends, into the analysis between obstructive factors and cognition of mainland China. Finally, increasing in cognition of mainland China will strength the intention of Taiwanese for employment and entrepreneurship in mainland China.

\section{CONCLUSION AND IMPLICATIONS}

As far as the current global economic development situation and cross-strait relationship are concerned, creating more opportunities for employment and entrepreneurship, constructing channels for employment and entrepreneurship, promoting cross strait economic and trade are the main focus of this paper. According to the results of questionnaire survey, because of the 
economic downturn, Taiwanese have relatively high willingness to work and start up in mainland China. Among the influential factors, supporting service and preferential policy will enhance the intention of employment and entrepreneurship, whereas the poor environment in the inability to adapt to social life will decline the intention of Taiwanese. Moreover, obtaining the experience and encouragement, strengthening the core competence, and enhancing the cognition of mainland China will have positive effect on intention of Taiwanese for employment and entrepreneurship in mainland China.

Based on the analysis aforementioned, this paper puts forward the following suggestions for Taiwanese to get a job and start-up in mainland China.

First of all, Taiwanese should pay more attention to the relevant policies issued by mainland's government. Recently, National Taiwan Office and the National Development and Reform Commission jointly issued the Measurements to Promote Cross-Strait Economic and Cultural Exchange and Cooperation. Under this circumstance, different provinces and regions have issued their own unique supporting plans, reflecting the mainland's determination to provide Taiwanese with a stage to display their talents and realize their aspirations. Therefore, understanding the relevant policies and making good use of preferential policies will be the prerequisite for Taiwanese successful employment and entrepreneurship in the mainland.

Secondly, to create job opportunity and entrepreneurial opportunity in mainland China by strengthening core competence and adaptability of Taiwanese. Although cross strait being same root, there are differences in political system, society and culture. Therefore, Taiwanese who are willing to work and start up in mainland should down-to-earth, which means Taiwanese should adjust themselves to the local environment. In addition, for core competence perspective, Taiwanese have the advantage of grasping details and demanding high quality. However, over attention on details, something else will be inevitably ignored. In this regard, Taiwanese should keep focusing on the details and strengthen overall thinking as well.

Thirdly, reducing the risk of employment and entrepreneurship by obtaining resource from relatives and friends in mainland. The empirical results shown that the relationships of relatives and friends will enhance intention of Taiwanese for employment and entrepreneurship in mainland. On the one hand, having relatives and friends in mainland can provide experience for Taiwanese and reduce the uncertainty of employment and entrepreneurship. On the other hand, Taiwanese can get a better understanding of the real situation of social development in the mainland by communicating with relatives and friends. Therefore, having relatives and friends working and starting up in mainland is the key factor affecting the intention of Taiwanese for employment and entrepreneurship in mainland.

Finally, transformation the understanding and improving cognition of mainland. Taiwanese's cognition of the mainland is generally low because of lacking of understanding the current development of mainland and the deviation in the cognition of the government. The empirical results also indicated that a large proportion of Taiwanese have not ever been to the mainland 
before. Therefore, Taiwanese could truly understand mainland through travelling, study, internship and exchanging. Additionally, holding various forms of cross-strait exchange activities is also an important way to enhance cognition of the mainland.

\section{REFERENCES}

Allport, G. W. (1966). Traits revisited. American Psychologist, 21, 1-10.

Aslam, T. M., Awan, A. S., \& Khan, T. M. (2012). Entrepreneurial intentions among university students of Punjab a Province of Pakistan. International Journal of Humanities and Social Science, 2(14), 114-120.

Deng, Q. M., Huang, Y. C., \& Yang, M. X. (2018). An analysis of the Taiwan youth's entrepreneurial intention in mainland China and its influencing factors: Based on 855 questionnaires. Taiwan Research Journal, (4), 31-37.

Esfandiar, K., Sharifi-Tehrani, M., Pratt, S., \& Altinay, L. (2019). Understanding entrepreneurial intentions: A developed integrated structural model approach. Journal of Business Research, 94, 172-182.

Guo, J. Y., \& Chen, Z. X. (2018). Research on the present incubation status of young people of Taiwan in mainland China and relative countermeasures. Decision and Information, (7), 111-117.

He, F., Liu, C. Y., \& Ma, D. (2016). An analysis of regional choice and factors of Taiwan youth for employment and entrepreneurship in mainland China: Based on the 1030 surveys from four Taiwan's universities. Research on Development, (5), 165-168.

He, H. L., Zhou, D. D., \& Liu, C. Y. (2016). How information source and recognition to mainland China affect the intention of Taiwan youth for employment and entrepreneurship: Based on the 1030 surveys from four Taiwan's universities. Research on Development, (4), 172-176.

Herring, C., \& Butler, J. S. (1991). Ethnicity and entrepreneurship in America: Toward and explanation of racial and ethnic group variations in self-employment. Sociological Perspectives, 34(2), 79-94.

Huang, J.-J., \& Lin, J.-Y. (2019). An analysis of the influence of intention of Taiwanese for employment and entrepreneurship in mainland China from the perspective of personal background difference. China Venture Capital, (10), 11-14.

Lan, Y.-H. (2001). A Study on the Relationships among the Cross-Cultural Training, Expatriate Skill and Expatriate Adjustment. Chung Yuan Christian University, Taoyuan.

Lee, W.-L. (2013). The effect of family environment to entrepreneurial intention and entrepreneurial behavior: A study of cross-strait entrepreneurs. Taiwan Journal of International Business Studies, 7(1), 71-94.

Li, W. R., Huang, K. J., Yang, Z. H., Wu, S. T., \& Zhao, J. E. (2013). Investigate the key successful factors of micro-business. Business Administration. Feng Chia University. Taichung City.

Liang, C. Y., Xia, J. C., \& Zhao, S. P. (2019). Relationship between entrepreneurial intentions and social network under the Internet situation: Empirical evidence from Chinese college students. Sciences \& Technology for Development, 15(1), 74-82. 
Lin, J.-Y. (2018). The Research on the Situation of Taiwan Youth for Entrepreneurship in Mainland China (2017). Retrieved from Taiwan.

Liu, C. Y. (2016). An analysis of policy demand of Taiwan youth for employment and entrepreneurship in mainland China: Based on the 1030 surveys from four Taiwan's universities. Morden Taiwan Studies, (6), 40-45.

Liu, C. Y., \& Chen, Z. G. (2018). The interpretation of the icberg model and its lifting path of environmental cognition inhibiting the willingness of Taaiwanese youths to work and strat a business in mainland China. Contemporary Youth Research, (6), 94-99.

Liu, C. Y., Chen, Z. G., \& Wang, H. H. (2019). An analysis on the willingness of youth Taiwanese to go to China from the perspective of identification: Based on a survey of 8 universities in Taiwan. China Youth Univeristy for Political Sciences, 38(3), 57-65.

Liu, C. Y., \& Li, N. (2016). Taiwan youths' "mainland impression" and "employment and entrepreneurial intention" in the perspective of information communication. Journal of Guangxi Normal University (Philosophy and Social Sciences Edition), 52(6), 40-45.

Liu, C. Y., Liu, F. Z., \& Zhang, J. S. (2017). Dislocation of expectation and cognition: A research on the "mainland impression" of Taiwan youth generation - Based on the questionnaire survey of 1030 university students from four university of Taiwan. Taiwan Research Journal, (2), 6-13.

Shan, L. Y. (2016). An Analysis of the Employment problems faced by Young people in Taiwan and the situation of starting businesses and Employment in the mainland China. Morden Taiwan Studies, (6), 34-39.

Sheng, J. Y. (2018). Current situation and future trends of cross-strait cooperation on business start-ups of the youth. Cross-Taiwan Strait Studies, (1), 35-43.

Tan, J. J. (2018). Research on problems in employment and entrepreneurship encountered by young people of Taiwan in mainland China and relative countermeasures: The case of Guangdong Province. Guangdong Economy, (5), 46-53.

Tsai, C.-C. (2011). The Factors that Influence the Willingness of Taiwanese Corporation Employees Working in China. Tamkang University, New Taipei City.

Turker, D., \& Selcuk, S. S. (2009). Which factors affect entrepreneurial intention of university students? Journal of European Industrial Training, 33(2), 142-159.

Wang, L., Preito, L., \& Hinrichs, K. T. (2010). Direct and indirect effects of individal and environmental factors on motivation for self-employment. Journal of Development Entrepreneurship, 15(4), 481-502.

Xie, Y. W. (2018). On the intention and motivation of Taiwan youth to go to mainland for employment and entrepreneurship: Based on the quetionnair survey of Taiwan's colleges and universities. journal of Guangxi Agriculture, 33(6), 40-45.

Yu, M. Z. (2005). An Empirical Study on the Relationship between Expatriate Compensation, Compensation Satisfaction, and Expatriate Willingness: The Case of Taiwanese Managers. Fu Jen Management Review, 12(1), 121-146.

Zhuang, P. Q. (2008). The research on the ability of cross-cultural cultivation of high-tech industry: The case of mainland China. National Yunlin University of Science and Technology, Yunlin. 